\title{
Relationship between Middle School Students' Frequency of Participation in Lab Activities and Scientific Epistemological Beliefs: Turkish Case
}

\author{
Hatice Esma OZBAY \\ Inonu University, Institute of Educational Sciences, 44280, Turkey \\ Email: esma.ozbay9@gmail.com \\ Mustafa Serdar KÖKSAL \\ Hacettepe University, Faculty of Education, 06800, Turkey \\ Email: bioeducator@gmail.com
}

\begin{abstract}
The purpose of this study is to investigate relationship of fifth, sixth, seventh and eighth grade students' scientific epistemological beliefs with their frequency of participating in laboratory activities. For this purpose, correlational study method was used. Sample of the study involved 301 students purposively selected from convenient schools. The data of the study was collected by a Likert type scale called "Scientific Epistemological Beliefs Scale" and information form about frequency of participating in laboratory activities and description of sample laboratory activities. The findings showed that majority of the students never participated in lab activities or participated in one time during one year. Also the fifth, sixth, seventh and eighth grade students' scientific epistemological beliefs were significantly related to their frequency of participating in laboratory activities. They are positively correlated to each other. However there were no significant relationships between the students' scientific epistemological beliefs and their frequency of participating in laboratory activities. Hence it can be claimed that participating in lab activities is associated with development of sophisticated scientific epistemological beliefs.
\end{abstract}

Index Terms-Scientific epistemological beliefs, laboratory activities, correlational study, middle school students, Turkish students.

\section{INTRODUCTION}

Epistemology as a term refers to the field involving definition of the knowledge, ways of knowledge production and ways of knowing (1). Epistemological beliefs involve individuals' beliefs about nature of knowledge and ways of knowing (2). For defining epistemological beliefs of individuals, different explanations were developed in the literature $(2,3,4)$. Perry defined epistemological beliefs as individuals' views regarding definition of knowledge, ways of knowledge gain, certainty of knowledge and verification of knowledge (3). Then Hofer made a definition but his definition limits epistemological beliefs to the beliefs about knowledge and knowing (5). However Hammer and Elby thought that beliefs about learning are part of epistemological beliefs and so they defined epistemological beliefs as beliefs about nature of knowing and learning (6). Actually Schommer provided a comprehensive definition and she also tested her definition by her instrument (Epistemological Beliefs Questionnaire) (4). Schommer's definition involves beliefs about nature of knowing, knowledge and learning. Previous studies using Schommer's instrument showed that epistemological beliefs of the students are associated with self-regulated learning strategy use (7), personal achievement goals (8), and academic achievement (9). Hence the epistemological beliefs of students should be considered in instructional planning. Tsai found that the students with sophisticated epistemological beliefs made frequent discussions and shares in group studies and preferred more free and student centered learning environments (10). Also Tsai found that that the students with sophisticated epistemological beliefs learned more than the students with traditional epistemological beliefs in teaching by science-technology-society issues (11).

Individuals with sophisticated epistemological beliefs believe that, knowledge is affected by the context hence it is a requirement to consider context for deciding on falseness or trueness of knowledge. Moreover they believe complex nature of knowledge with associated components and construction of knowledge by individuals via reason, data and evidence. In addition they treat learning ability as a changeable ability and learning as a changing characteristic with personal struggle (12). Hofer and Pintrich mentioned three characteristics of epistemological beliefs.

1. Epistemological beliefs are developmental.

2. Epistemological beliefs are accepted as a form of belief system and they are associated with learning.

3. Epistemological beliefs might be defined as theories or epistemological resources of an individual about knowledge and knowing. These 
theories and resources affect learning in certain contexts (2).

In the last 20 years, educational studies about epistemological beliefs were increased due to its close relationship with learning and teaching (2). William Perry initiated studies on epistemological beliefs and Perry created a model for explaining individuals' beliefs about "nature of knowledge" and "source of knowledge", and their perceptions about themselves as learner and knower (13). Then Perry investigated development of the beliefs of college students. In following years Belenky, Clinchy, Goldberger and Tarule looked the problem about epistemological beliefs from gender perspective (14). They established the model of Women's Ways of Knowing and they investigated difference between beliefs of women and men about knowing and learning. Then Schommer-Aikins criticized existent models of epistemological beliefs and she suggested a multidimensional system for epistemological beliefs and made emphasis on importance of beliefs about knowledge and learning (4). She also claimed existence of partially independent epistemological beliefs and suggested fivedimension model of epistemological beliefs system. Khun's Argumentative Reasoning Model (15) and Kuhn's Model of Intellectual Values (16) changed the previous perspectives on epistemological beliefs. In these models critical thinking and argumentation were added into the models to explain epistemological beliefs in action. The studies using the models summarized above showed importance of epistemological beliefs for teaching and learning. Especially studies in the field of science education represented association of epistemological beliefs (scientific epistemological beliefs) with learning environment preference, attitude towards science, science achievement and learning motivation (9, 17, 11, 18, 19).

Actually epistemological beliefs are both domain domain-dependent and domain-general $(20,21)$. However domain-dependent epistemological beliefs have a direct effect on learning while domain-general epistemological beliefs have indirect effects on learning (22). Based on domain-dependent nature of epistemological beliefs, some of the researchers (23) considered scientific epistemological beliefs as a research area. They used Schommer's model as a frame of their study (4). The researchers found four-dimensional structure of scientific epistemological beliefs. These dimensions involved certainty, verification, improvement and resource. The certainty dimension is about beliefs regarding tentativeness of knowledge while the resource dimension is related to beliefs about acceptance of authority, scientists, and books as knowledge resources or rejecting them. The improvement dimension is about beliefs regarding change in learning ability over time while the verification dimension involves beliefs about usage of experiment for verifying conclusions or usage of other ways (23). Even though many different studies have been conducted about these dimensions these studies have stayed in the descriptive level $(9,24,25)$. However there is a need to investigate effect of different knowledge production contexts on scientific epistemological beliefs. As a knowledge production context, science lab activities might be related to development of scientific epistemological beliefs of students. Since their beliefs regarding scientific knowledge and science are shaped by these activities $(26,27,28)$ or preferences for making lab activities are shaped scientific epistemological beliefs (29). In spite of importance of lab activities in knowledge production and development of epistemological beliefs, the relationship between frequency of participating in laboratory activities by which knowledge production is experienced, and scientific epistemological beliefs have not been studied enough. It is a requirement to investigate the relationship since Tsai found that students with sophisticated epistemological beliefs had preference to learn by constructivist processes and they were more active in making explanations and commenting during laboratory activities (10). At the same time it was observed that these students learned meaningfully scientific concepts represented in lab. Moreover Kang and Wallace pointed out those epistemological beliefs of science teachers were reasons for not choosing and applying laboratory activities in their teaching (29). The studies summarized above gave evidence for potential relationship of frequency of participating in laboratory activities with scientific epistemological beliefs, but it is still not direct evidence to investigate the relationship. Hence there is not enough study considering the laboratory as a knowledge production place $(30,31,32)$ and investigating directly the relationship of frequency of participating in laboratory activities with scientific epistemological beliefs. Laboratory activities provide the best way to study on learning nature of science and scientific processes $(26,27,28)$. As a result, the purpose of this study is to investigate relationship of sixth, seventh and eighth grade students' scientific epistemological beliefs with their frequency of participating in laboratory activities.

\section{METHOD}

In this study correlational research method was preferred. The data of the study was analyzed by using Spearman Rho correlation and classification of examples regarding lab activities. A total of 301 (152 females, 149 males) participated in the study. To prevent loss of time, money and effort, convenient sampling method was chosen (33). The descriptive statistical results about the participants are in table 1 . 
Table 1. Descriptive statistics about the participants

\begin{tabular}{|c|c|c|c|c|}
\hline Grade Level & \multicolumn{2}{|c|}{$\begin{array}{l}\text { Number of The } \\
\text { Participants }\end{array}$} & \multicolumn{2}{|c|}{$\%$} \\
\hline $5^{\text {th }}$ grade & \multicolumn{2}{|c|}{36} & \multicolumn{2}{|c|}{12,0} \\
\hline $6^{\text {th }}$ grade & \multicolumn{2}{|c|}{53} & \multicolumn{2}{|c|}{17,6} \\
\hline 7 th grade & \multicolumn{2}{|c|}{136} & \multicolumn{2}{|c|}{45,2} \\
\hline $8^{\text {th }}$ grade & \multicolumn{2}{|c|}{76} & \multicolumn{2}{|c|}{25,2} \\
\hline \multicolumn{5}{|l|}{ Gender } \\
\hline Male & \multicolumn{2}{|c|}{152} & \multicolumn{2}{|c|}{50,5} \\
\hline Female & \multicolumn{2}{|c|}{149} & \multicolumn{2}{|c|}{49,5} \\
\hline Educational status & Mother & Father & $\begin{array}{c}\text { Mother } \\
(\%)\end{array}$ & $\begin{array}{c}\text { Father } \\
(\%)\end{array}$ \\
\hline Illiterate & 23 & 6 & 7,6 & 2,0 \\
\hline Elementary school & 73 & 52 & 24,3 & 17,3 \\
\hline Middle school & 62 & 45 & 20,6 & 15,0 \\
\hline High school & 86 & 94 & 28,6 & 31,2 \\
\hline University level & 51 & 91 & 16,9 & 30,2 \\
\hline Graduate level & 4 & 13 & 1,3 & 4,3 \\
\hline \multicolumn{5}{|l|}{$\begin{array}{c}\text { Classes taken about } \\
\text { epistemology }\end{array}$} \\
\hline Yes & \multicolumn{2}{|c|}{0} & \multicolumn{2}{|c|}{0.00} \\
\hline No & \multicolumn{2}{|c|}{301} & \multicolumn{2}{|c|}{100.0} \\
\hline \multicolumn{5}{|l|}{$\begin{array}{l}\text { Participation in } \\
\text { conferences about } \\
\text { epistemology }\end{array}$} \\
\hline Yes & \multicolumn{2}{|c|}{0} & \multicolumn{2}{|c|}{0.00} \\
\hline No & \multicolumn{2}{|c|}{301} & \multicolumn{2}{|c|}{100.0} \\
\hline \multicolumn{5}{|l|}{$\begin{array}{c}\text { Frequency of } \\
\text { participation in the } \\
\text { lab activities of middle } \\
\text { school }\end{array}$} \\
\hline "Never" up to date & \multicolumn{2}{|c|}{110} & \multicolumn{2}{|c|}{36,5} \\
\hline $\begin{array}{l}\text { "Once a year" up to } \\
\text { date }\end{array}$ & \multicolumn{2}{|c|}{76} & \multicolumn{2}{|c|}{25,2} \\
\hline $\begin{array}{c}\text { "1-14 times in a year" } \\
\text { up to date }\end{array}$ & \multicolumn{2}{|c|}{104} & \multicolumn{2}{|c|}{34,6} \\
\hline $\begin{array}{c}\text { "More than } 14 \text { times in } \\
\text { a year" up to date }\end{array}$ & \multicolumn{2}{|c|}{11} & & \\
\hline Total & & & & \\
\hline
\end{tabular}

When looked at table 1 , it is observed that most of the participants involved $7^{\text {th }}$ and $8^{\text {th }}$ grade students while the least number of the participants was from $5^{\text {th }}$ grade students. Rate of male students to female students was very close to each other. At the same time majority of the parents were high school and university graduates. As another important descriptive data, frequency of no participation in lab activities was the highest value among the participants. Very few number of the participant went for lab activities more than 14 times.

\section{A. Measurement Instruments}

In this study, personal characteristics and scientific epistemological beliefs of the students were determined by using personal information question form and scientific epistemological beliefs scale. The scientific epistemological beliefs scale was originally developed by Conley, Pintrich, Vekiri and Harrison (23) for a group of $5^{\text {th }}$ grade students and the adaptation of the scale into Turkish was done by Kurt (34). The scale is consisted of 26 Likert type items with five options. The frequency of the students' participation in lab activities was determined by a questionnaire having items asking number of participating in lab activities "in a year up to current time" and also 5 examples for their lab activities were also asked. In table 2 the question about the examples to lab activities is represented.

Table 2. Could you give us 5 examples for your lab activities during your previous participation in lab activities?

\begin{tabular}{|l|}
\hline Activity 1. \\
\hline Activity 2. \\
\hline Activity 3. \\
\hline Activity 4. \\
\hline Activity 5. \\
\hline
\end{tabular}

The items and Likert scaling of the scientific epistemological beliefs scale are represented in table 3 .

By using original items of the scientific epistemological belief, validity and reliability studies were done for the sample of this study. In the scale, there were four dimensions: Verification, improvement, certainty and resource. To check this factorial structure, confirmatory factor analysis was done. In the analysis two sets of indexes were used, they were fit indexes and non-fit indexes. As fit indexes, CFI, GFI and CMIN/DF ratio were considered while RMSEA were considered as non-fit index. The results associated with confirmatory factor analysis are in table 4 . 
Table 3. Items and scaling of the scientific epistemological beliefs scale

\begin{tabular}{|c|c|c|c|c|c|c|}
\hline \multicolumn{2}{|r|}{$\begin{array}{l}\text { Read the sentences below and put an } \mathrm{X} \text { on the box you personally } \\
\text { think is correct. Put a single } \mathrm{X} \text { per question. }\end{array}$} & \multirow[t]{2}{*}{$\begin{array}{l}\text { I definitely } \\
\text { disagree. }\end{array}$} & \multirow[t]{2}{*}{ I disagree. } & \multirow[t]{2}{*}{$\begin{array}{c}\text { I am } \\
\text { hesitant. }\end{array}$} & \multirow[t]{2}{*}{ I agree. } & \multirow[t]{2}{*}{$\begin{array}{l}\text { I definitely } \\
\text { agree. }\end{array}$} \\
\hline 1 & All people have to believe in what scientists say.* & & & & & \\
\hline 2 & İn science all questions have only one correct answer.* & & & & & \\
\hline 3 & $\begin{array}{l}\text { In scientific experiments ideas, events are thought of and } \\
\text { come forth from curiosity. }\end{array}$ & & & & & \\
\hline 4 & $\begin{array}{l}\text { Today, some scientific thoughts are different from what } \\
\text { scientists thought of in the past. }\end{array}$ & & & & & \\
\hline 5 & $\begin{array}{l}\text { Before starting an experiment there is benefit in having an } \\
\text { idea about it first. }\end{array}$ & & & & & \\
\hline 6 & You have to believe what is written in scientific books.* & & & & & \\
\hline 7 & $\begin{array}{l}\text { The most important part of a scientific study is to reach a } \\
\text { correct answer.* }\end{array}$ & & & & & \\
\hline 8 & Information in scientific book can change sometimes. & & & & & \\
\hline 9 & $\begin{array}{l}\text { In scientific studies there can be different ways to test } \\
\text { thoughts. }\end{array}$ & & & & & \\
\hline 10 & In science class everything the teacher says is correct.* & & & & & \\
\hline 11 & $\begin{array}{l}\text { Thoughts in science come forth from your own experiments } \\
\text { and questions you ask yourself. }\end{array}$ & & & & & \\
\hline 12 & $\begin{array}{l}\text { Scientists know practically everything there is to know } \\
\text { about science, there is nothing left to learn.* }\end{array}$ & & & & & \\
\hline 13 & $\begin{array}{l}\text { There are some questions that even scientists cannot } \\
\text { answer. }\end{array}$ & & & & & \\
\hline 14 & $\begin{array}{l}\text { Experimenting and scientific studies are an important part } \\
\text { of learning how things happen. }\end{array}$ & & & & & \\
\hline 15 & $\begin{array}{l}\text { You can be sure that everything you read in a science book } \\
\text { is corrent.* }\end{array}$ & & & & & \\
\hline 16 & Scientific information is always correct.* & & & & & \\
\hline 17 & Scientific thoughts may sometimes change. & & & & & \\
\hline 18 & To be sure about results, it is good to redo experiments. & & & & & \\
\hline 19 & Only scientists know for sure what is correct in science. & & & & & \\
\hline 20 & $\begin{array}{l}\text { The result a scientist receives from an experiment is the } \\
\text { only answer.* }\end{array}$ & & & & & \\
\hline 21 & $\begin{array}{l}\text { New discoveries may change what scientists thought to be } \\
\text { true. }\end{array}$ & & & & & \\
\hline 22 & $\begin{array}{l}\text { Good ideas in science are not only from scientists but may } \\
\text { also be from normal people. }\end{array}$ & & & & & \\
\hline 23 & $\begin{array}{l}\text { Scientists always agree upon what is correct and what isn't } \\
\text { in science.* }\end{array}$ & & & & & \\
\hline 24 & $\begin{array}{l}\text { Best conclusions are based on evidence obtained from the } \\
\text { results of different experiments. }\end{array}$ & & & & & \\
\hline 25 & $\begin{array}{l}\text { Scientists may change what they accept as correct in } \\
\text { science. }\end{array}$ & & & & & \\
\hline 26 & $\begin{array}{l}\text { Experimenting is the best way to be sure if something is } \\
\text { correct or not.* }\end{array}$ & & & & & \\
\hline
\end{tabular}

Table 4.Confirmatory factor analysis of scientific epistemological beliefs scale

\begin{tabular}{|l|l|}
\hline Indexes & Values \\
\hline CMIN/DF & 2.13 \\
\hline GFI & 0.90 \\
\hline CFI & 0.85 \\
\hline RMSEA & 0.05 \\
\hline
\end{tabular}

Table 4 represented that CFI and GFI values are 0.90 and 0.85 respectively and they are acceptable values for confirming previous factorial structure. Moreover RMSEA value was 0.05 and this was also acceptable (35). Results of reliability analysis can be seen in table 5 .
Table 5. The Reliability value of the scientific epistemological scale and descriptive values on the scores about the scale.

\begin{tabular}{|l|l|}
\hline Item Number & 26 \\
\hline Cronbach Alpha & 0.77 \\
\hline Mean & 88.72 \\
\hline Variance & 164.60 \\
\hline Standard Deviation & 12.83 \\
\hline
\end{tabular}

In table 5 it can be seen that Chronbach alpha value (0.77) has an acceptable value. Hatcher and Stepanski stated that Cronbach Alpha value as low as 0.55 is acceptable statistical value (as cited in 35). 


\section{FINDINGS}

In this study three different sets of findings are represented. The first is about examples of lab activities while the second is about descriptive values regarding scientific epistemological beliefs. The third set is about correlational findings between frequency of participating in lab activities and scientific epistemological beliefs. For the first set of findings, categorization frame involving "No examples", "No classification", "Demonstration", "Observation", "Comparison", "Correlational" and "Experimental" categories were used (Frankel \& Wallen, 2006). Examples of the participants for lab activities and their frequencies are represented in table 6.

Table 6. Examples of the participants for lab activities and their frequencies.

\begin{tabular}{|c|c|c|c|c|c|}
\hline \multirow{2}{*}{$\begin{array}{l}\text { Examples } \\
\text { Activities }\end{array}$} & \multirow{2}{*}{ Laboratory } & \multicolumn{2}{|c|}{ Example for Activity 1 Box } & \multicolumn{2}{|c|}{ Example for Activity 2 Box } \\
\hline & & Number of Participants & $\%$ & $\begin{array}{l}\text { Number of } \\
\text { Participants }\end{array}$ & $\%$ \\
\hline No Example & & 67 & 22,3 & 99 & 32,9 \\
\hline No Classification & & 131 & 43,5 & 111 & 36,9 \\
\hline Demonstration & & 27 & 9,0 & 24 & 8,0 \\
\hline Observation & & 72 & 23,9 & 59 & 19,6 \\
\hline Comparison & & 3 & 1,0 & 6 & 2,0 \\
\hline Correlational & & - & - & - & - \\
\hline Experimental & & 1 & 0,3 & 2 & 0,7 \\
\hline
\end{tabular}

Second part of table 6 .

\begin{tabular}{|l|l|l|l|l|l|}
\hline \multicolumn{2}{|l|}{ Example for Activity 3 Box } & \multicolumn{2}{l|}{ Example for Activity 4 Box } & \multicolumn{2}{l|}{ Example for Activity 5 Box } \\
\hline Number of Participants & $\%$ & Number of Participants & $\%$ & Number of Participants & $\%$ \\
\hline 142 & 47,2 & 177 & 58,8 & 210 & 69,8 \\
\hline 94 & 31,2 & 79 & 26,2 & 51 & 16,9 \\
\hline 11 & 3,7 & 10 & 3,3 & 10 & 3,3 \\
\hline 48 & 15,9 & 33 & 11,0 & 29 & 9,6 \\
\hline 2 & 0,7 & 1 & 0,3 & 1 & 0,3 \\
\hline 1 & 0,3 & - & - & - & - \\
\hline 3 & 1,0 & 1 & 0,3 & - & - \\
\hline
\end{tabular}

When table 6 is examined it is seen that majority of the participants cannot give any example to laboratory activities or their examples could not classified due to the vague nature of their examples. For the second set of the findings descriptive values of scientific epistemological beliefs scale scores were calculated. They are represented in table 7.

Table 7. Descriptive statistics of the scores on scientific epistemological beliefs scale.

\begin{tabular}{|c|c|c|c|c|}
\hline Dimensions & Mean & $\begin{array}{c}\text { Standard } \\
\text { Deviation }\end{array}$ & Skewness & Kurtosis \\
\hline Total Score & 3,39 & 0,44 & $-0,20$ & 0,24 \\
\hline $\begin{array}{c}\text { Verification } \\
\text { Dimension }\end{array}$ & 3,45 & 0,66 & $-0,81$ & 0,38 \\
\hline $\begin{array}{c}\text { Improvemen } \\
\text { t Dimension }\end{array}$ & 3,48 & 0,71 & $-0,56$ & 0,47 \\
\hline $\begin{array}{c}\text { Resource } \\
\text { Dimension }\end{array}$ & 3,25 & 0,55 & $-0,12$ & $-0,26$ \\
\hline $\begin{array}{c}\text { Certainty } \\
\text { Dimension }\end{array}$ & 3,31 & 0,78 & $-0,28$ & $-0,14$ \\
\hline
\end{tabular}

Table 7 showed that means of the scores regarding the scale and its dimensions are close to each other. However 4 or more point on the scales is required to say that individuals have sophisticated scientific epistemological beliefs. According to table 7, mean value of total scores of the participants is below 4 hence it cannot be said that the students have sophisticated scientific epistemological beliefs in general. When the dimensions are taken into consideration separately it is observed that the students are not sufficient enough to have sophisticated epistemological beliefs about the dimensions. For the third set of findings, possible correlation between scientific epistemological beliefs and frequency of the participation in the lab activities was analyzed. For this purpose Spearman rho correlation was used and Bonferroni adjustment for holding Type I error rate constant was done $(0.05 / 5=0.01)$. The results on the correlational analysis are represented in table 8. 
Table 8. Correlational analysis between scientific epistemological beliefs and frequency of the participation in lab activities.

\begin{tabular}{|c|c|c|c|c|c|c|}
\hline Variabl & \multirow{2}{*}{$\begin{array}{c}\text { Statisti } \\
\text { eal }\end{array}$} & \multicolumn{5}{|c|}{ Scientific Epistemological Beliefs } \\
\cline { 3 - 7 } & Values & Ver. & Imp. & Res & Cer & Total \\
\hline $\begin{array}{c}\text { Freque } \\
\text { ncy of } \\
\text { the }\end{array}$ & $\begin{array}{c}\text { Spearm } \\
\text { an's } \\
\text { Rho }\end{array}$ & 0,13 & 0,08 & 0,09 & 0,10 & $0,16^{*}$ \\
$\begin{array}{c}\text { Partici } \\
\text { pation } \\
\text { in }\end{array}$ & $\mathrm{P}$ & & & & & \\
$\begin{array}{c}\text { Labora } \\
\text { tory } \\
\text { Activit } \\
\text { ies }\end{array}$ & & 0,02 & 0,15 & 0,14 & 0,10 & 0,00 \\
*statistically significant correlation & & & & \\
\hline
\end{tabular}

The results showed that there was a statistically significant positive correlation between total score on scientific epistemological beliefs and frequency of the participation in lab activities $(p<0.01)$. This correlation means that when frequency of the participation in lab activities is increased number of sophisticated scientific epistemological beliefs of the students is also increased, or vice versa.

\section{DISCUSSION AND SUGGESTIONS}

Based on the findings of this study, it is seen that middle school students do not have sophisticated scientific epistemological beliefs. This finding supports the previous studies' findings. Boz, Aydemir and Aydemir's investigated scientific epistemological beliefs of $4^{\text {th }}, 6^{\text {th }}$ and $8^{\text {th }}$ grade students by using Conley et al's instrument (36). They found unsophisticated scientific epistemological beliefs of the students about verification, improvement and resource dimensions. Again Sadiç, Çam and Topçu conducted a study with $1604^{\text {th }}$, 6th and $8^{\text {th }}$ grade students and the results showed that they did not have sophisticated beliefs about 'resource of knowledge' dimension (37). One year later Yeşilyurt made a research and their findings showed that $7^{\text {th }}$ and $8^{\text {th }}$ grade students $(n=324)$ were not sophisticated about the dimensions of scientific epistemological beliefs except for verification dimension (25). Hence it can be said that the findings of this study supported the literature.

The other finding of this research shows that there is a positive statistically significant relationship between frequency of participating in laboratory activities and scientific epistemological beliefs. Meaning of the relationship is two-sided that sophisticated scientific epistemological beliefs leads to preference to participate frequently in lab activities or preference to participate frequently in lab activities leads to development of sophisticated scientific epistemological beliefs. This situation needs a further regression analysis. However some previous studies focused on this issue. Tsai showed that students choosing epistemologically more constructivist learning environments are more active in lab studies (10). Qualitative findings of the researcher also explained that the students choosing epistemologically more constructivist learning environments see lab activities as knowledge production process. Actually laboratories provide the best environment to learn about nature of science and scientific processes $(26,27,28)$. Some of the studies show that changing epistemological aspects of laboratory activities affect the process experienced by the students $(38,39)$. In his study Dumbar changed the goal of the lab activities from routine verification goal to explanation goal (38). He found that the students studying to make explanations in lab activities made more systematic investigations. This situation shows that changes in epistemological nature of laboratory experiences also changes quality of lab activities in terms of teaching. Schauble et al. supported this idea that explaining scientific goals of the experiments to $5^{\text {th }}$ grade students helped them design better qualified experiments (39). These results from the literature showed that participating in laboratory activities is associated with scientific epistemological beliefs. However nature of the relationship should be investigated by using path analysis or regression methods.

Despite the value of the results obtained in this study there are some important limitations. The limitations are low number of participants, use of non-parametric statistics and acceptance of students' self-reports about lab activities as data. Based on these limitations it can be suggested that random sampling should be done in future studies. Following this sampling parametric statistical techniques involving path analysis or regression should be applied. Also the study can be re-conducted in a longitudinal manner. At the same time during the laboratory activities the researchers can observe the nature of the activities and then classify them for further analysis.

\section{REFERENCES}

[1] Deryakulu, D. Üniversite öğrencilerinin öğrenme ve ders çalışma stratejileri ile epistemolojik inanışları arasındaki ilişki, Kuram ve Uygulamada Eğitim Yönetimi, 38, 230249. 2004.

[2] Hofer, B.K. \& Pintrich, P. R. (Eds.). Personel epistemology: The psychology of beliefs about knowledge and knowing. Mahwah, NJ: Lawrence Erlbaumassociates. 2002.

[3] Perry, W.G. (1981). Cognitive and ethical growth: The making of meaning. In a. Chickering (ed.), The Modern American Collage (pp. 76-116). San Francisco: JosseyBass.

[4] Schommer, M. Effects of beliefs about the nature of knowledge on comprehension. Journal of Educational Psychology, 82, 498-504. 1990

[5] Hofer, B. Personal epistemology research: Implications for learning and instruction, Educational Psychology Review, 13(4), 353-382. 2001.

[6] Hammer, D \& Elby,A. On the form of a personal epistemology, B.K. Hofer, P.R. Pintrich (Eds.), Personal epistemology: The psychology of beliefs about knowledge and knowing. Erlbaum, Mahwah. 2002. pp. 169-190.

[7] Metallidou, P. Epistemological beliefs as predictors of self-regulated learning strategies in middle school students. School Psychology International, 34(3), 283-298. 2012. 
[8] Neber, H., \& Schommer-Aikins, M. Self-regulated science learning with gifted students: The role of cognitive, motivational, epistemological, and environmental variables. High Ability Studies, 13, 5974.2002.

[9] Topçu, M. S., \& Yılmaz-Tüzün, Ö. Elementary students' metacognition an epistemological beliefs considering science achievement, gender and socioeconomic status. İlkögretim Online, 8(3), 676-693.2009.

[10] Tsai, C.C. Laboratory exercises help me memorize the scientific truths: A study of eighth graders' scientific epistemological views and learning in laboratory activities, Science Education, 83 (6), 654-674.1999.

[11] Tsai, C. C. Relationships between student scientific epistemological beliefs and perceptions of constructivist learning environments. Educational Research, 42, 193205.2000 .

[12] Deryakulu, D. Denetim odağı ve epistemolojik inançların ögretim materyalini kavramayı denetleme türü ve düzeyi ile ilişkisi. Hacettepe Eğitim Fakültesi Dergisi 22, 5561.2002.

[13] Perry, W. G. Forms of intellectual and ethical development in the college years: A scheme. New York: Holt, Rinehart and Winston.1970.

[14] Belenky, M. F., Clinchy, B. M., Goldberger, N. R., \& Tarule, J. M. Women's ways of knowing: The development of self voice and mind. New York: Basic Books.1986.

[15] Kuhn, D. The skills of argument. Cambridge, England: Cambridge University Press.1991.

[16] Kuhn, D. Education for thinking. Cambridge, MA: Harvard University Press. 2005.

[17] Tsai, C. C. Content analysis of Taiwanese 14 yearolds' information processing operations shown in cognitive structures following physics instruction, with relations to science attain mentand scientific epistemological beliefs. Research in Science \&Technological Education, 17(2), 125-138. 1999.

[18] Özkal, K., Tekkaya, C., Çakıroğlu, J., \& Sungur, S. A conceptual model of relation ships among constructivist learning environment perceptions, epistemological beliefs, and learning approaches. Learning and Individual Difference, 9 (1), 71-79.2009.

[19] Chen, J. \& Pajares, F. Implicit theories of ability of Grade 6 science students: Relation to epistemological beliefs and academic motivation and achievement in science, Contemporary Educational Psychology, 35(1), 7587.2010.

[20] Hofer, B. Dimensionality and disciplinary differences in personal epistemology. Contemporary Educational Psychology, 25, 378-405. 2000.

[21] Muis, K., Bendixen, L. D., \& Haerle, F. C. Domaingenerality and domain specificity in personal epistemology research: Philosophical and empirical reflections in the development of a theoretical framework. Educational Psychology Review, 18, 3-54. 2006.

[22] Schommer-Aikins, M. \& Duell, O. K. Domain specific and general epistemological beliefs. Their effects on mathematics. Revista de Investigación Educativa, 31 (2), 317-330.2013.

[23] Conley, M. A., Pintrich, R. P., Vekiri L. \& Harrison D. Changes in epistemologicabeliefs in elementary science students. Contemporary Educational Psychology, 29, 186204.2004.
[24] Yenice, N. \& Ozden, B. Analysis of scientific epistemological beliefs of eighth graders. International Journal of Education in Mathematics, Science and Technology, 1(2), 107-115.2013.

[25] Yeşilyurt, E. İlköğretim okulu öğrencilerinin bilimsel epistemolojik inançları, International Journal of Social Science, 6 (1), 1587-1609. 2013.

[26] Blosser, P. E. The role of the laboratory in science teaching. Research matters to the science teacher [Online]. Available: http://science.coe.uwf.edu/NARST/research/labs.htm. 1990.

[27] Layton, D. Students laboratory practice and the history and philosophy of science. In E.Hegarty-Hazel (Ed.), The student laboratory and the science curriculum. London: Routledge.1990.pp. 37-59.

[28] Lazarowitz, R.,\& Tamir, P. Research on using laboratory instruction in science. In D. L.Gabel (Ed.), Handbook of research on science teaching and learning. New York:Macmillan. 1994. pp. 94-128.

[29] Kang, N.H. \& Wallace, C.S. Secondary science teachers' use of laboratory activities: Linking epistemological beliefs, goals, and practices. Science Education, 89(1), 140-165. 2005.

[30] Ozdem, Y., Ertepinar, H., Cakiroglu, J., \& Erduran, S. The nature of pre-service science teachers' argumentation in inquiry-oriented laboratory context. International Journal of Science Education, 35(15), 2559-2586.2013.

[31] McDonald, C.V. An examination of preservice primary teachers' written arguments in an open inquiry laboratory task, Science Education International, 24 (3), 254-281. 2013.

[32] Beck,C., Butler, A. \& da Silva, K.B. Promoting inquirybased teaching in laboratory courses: are we meeting the grade?, CBE Life Science Education, 13(3), 444-452.2014.

[33] Fraenkel, J.R., \& Wallen, N.E. How to design and evaluate research in education. New York: McGraw-Hill. 2006.

[34] Kurt, F. Cinsiyetin, Sınıf Seviyesinin, Eğitim Gördüklerì Alanların, Öğrencilerin Epistemolojik İnançları Üzerindeki Etkisi. (Yayımlanmış Yüksek Lisans Tezi) Orta Doğu Teknik Üniversitesi / Sosyal Bilimler Enstitüsü, Ankara. 2009.

[35] Köksal, M.S. \& Çakıroğlu, J. Development of nature of science scale (NSS) for advanced science students. Journal of Baltic Science Education, 9, 87-98. 2010.

[36] Boz Y., Aydemir M.,\& Aydemir N. Türkiye'deki 4., 6. ve 8. sınıf ilköğretim öğrencilerinin epistemolojik inançları. Ilkögrretim Online, 10(3), 1191-1201. 2011.

[37] Sadıç A., Çam A. \&Topçu M.S. İlköğretim Öğrencilerinin Epistemolojik İnançlarının Cinsiyet ve Sınıf Düzeyine Göre İncelenmesi. Muğla Üniversitesi. Muğla.http://kongre.nigde.edu.tr/xufbmek/dosyalar/tam metin/pdf/2266-18_05_2012-14_43_19.pdf. 2012.

[38] Dunbar, K. Concept discovery in a scientific domain. Cognitive Science, 17, 397-434. 1993.

[39] Schauble, L.,Glaser, R., Duschl, R. A., Schulze, S., \& John, J. Students' understanding of the objectives and procedures of experimentation in the science classroom. Journal of the Learning Sciences, 4(2), 131-166. 1995. 


\section{Authors' Profiles}

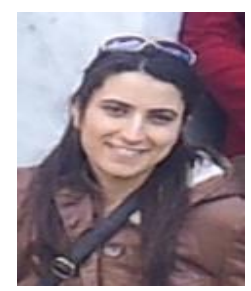

Hatice Esma Özbay has degrees of BE and MS from Inonu University Turkey. She has been working as a science teacher over 3 years. She is currently a $\mathrm{PhD}$ student in Inonu University, Malatya, Turkey.
Manuscript received 01 July 2015; revised 28 July 2015; accepted 06 November 2015.

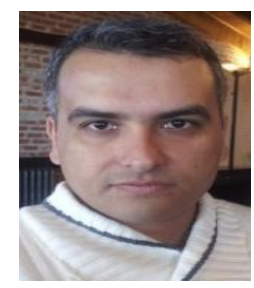

Dr. Mustafa Serdar Koksal is an associate professor at the Department of Science Education, Inonu University. Inteaching, he has been focusing on using explicit reflective approach for teaching NOS. In research, his current interests include epistemological beliefs, risk taking and argumentation. Dr. Koksal received his $\mathrm{PhD}$ degree from Faculty of Education in Middle East Technical University. He is a member of ESERA and IRATDE.

How to cite this paper: Hatice Esma OZBAY, Mustafa Serdar KÖKSAL,"Relationship between Middle School Students' Frequency of Participation in Lab Activities and Scientific Epistemological Beliefs: Turkish Case", IJMECS, vol.7, no.12, pp.1-8, 2015.DOI: 10.5815/ijmecs.2015.12.01 